\title{
Physical activity, evaluation of menopause, life satisfaction and influence tactics in marriage of perimenopausal women
}

\section{BACKGROUND}

Domination of the biomedical approach to menopause may imply creation of negative attitudes to the phenomenon, and at the same time negatively affect women's life satisfaction and behaviour in the family. It is assumed that physical activity may be a defensive factor, as this type of activity may reduce the intensity of menopause symptoms. The aim of the research was to determine the relation between menopause evaluation, life satisfaction and tactics of influence employed in marriage by women who differ in involvement in physical exercise.

\section{PARTICIPANTS AND PROCEDURE}

The research was conducted among 90 women, at the age of 45-55: 45 physically active women and 45 women who do not engage in any physical activity. The following research methods were used: the Menopause Evaluation Scale, the Satisfaction With Life Scale (SWLS) and the Questionnaire of Influence in Close Relations of Women and Men.

\section{RESULTS}

Positive evaluation of menopause was related to involvement in physical exercise as well as to a stronger tendency to use positive strategies of exerting influence on one's spouse. The research also showed a slight correlation between life satisfaction and involvement in physical exercise. Negative evaluation of menopause was related to avoiding physical activity.

\section{CONCLUSIONS}

Physical activity is more frequently related to a positive attitude towards menopause and the use of more positive tactics of exerting influence on one's spouse, and slightly positively conducive to one's life satisfaction level.

\section{KEY WORDS}

physical activity; menopause evaluation; life satisfaction; tactics of influence in marriage

ORGANIZATION - Department of Social and Environmental Psychology, Institute of Psychology, University of Silesia,

Katowice, Poland

AUthors' CONTRIBUtions - A: Study design - B: Data collection - C: Statistical analysis - D: Data interpretation .

E: Manuscript preparation · F: Literature search · G: Funds collection

Corresponding Author - Prof. Eugenia Mandal, Department of Social and Environmental Psychology, Institute of Psychology, University of Silesia, 53 Grażyńskiego Str., 40-126 Katowice, Poland, e-mail: eugenia.mandal@us.edu.pl

to Cite This ARTICLE - Mandal, E., \& Sitko-Dominik, M. (2017). Physical activity, evaluation of menopause, life

satisfaction and influence tactics in marriage of perimenopausal women. Health Psychology Report, 5(1), 48-54.

doi: 10.5114/hpr.2017.62709

RECEIVED 22.03.2016 · REVIEWED 10.05.2016 · ACCEPTED 30.05.2016 · PUBLISHED 19.10.2016 


\section{BACKGROUND}

Women obtain information about menopause first of all from popular literature and common knowledge (Randall, 1993). That is why the mass media present menopause in terms of a negative experience and identify it as illness (Gannon \& Stevens, 1998), which often contributes to creating a negative stereotype of menopause. One reason for this state of affairs may be presenting menopause from men's point of view; it is just among men and young people that a negative stereotype of the woman experiencing menopause exists (Bielawska-Batorowicz, Cieślik, \& Cwalina, 2003).

However, in spite of the negative image of menopause, many women tend to perceive it as a natural stage of life (Adler et al., 2000), and some of them notice some positive aspects of menopause (Hvas, 2001). Women's attitude to menopause depends not only on the socio-cultural context, but also on their experience and perception of menopause (Avis $\&$ McKinlay, 1991). A positive attitude towards menopause protects women from experiencing depression symptoms (Bloch, 2002).

In Western culture, the cult of beauty and youth contributes greatly to perpetuating a negative image of menopause. The necessity to meet the requirements of the ideal of a slim figure dominating in the culture, according to subjectification theory, may lead to the occurrence of negative repercussions consisting in experiencing shame and anxiety, and as a consequence it may lead to a decrease in the sense of well-being (Fredrickson \& Roberts, 1997). Moreover, women who report experiencing few menopause symptoms are more satisfied with their body appearance (Bloch, 2002). Having a negative attitude towards menopause leads to deriving less satisfaction from their body image and has a negative impact on evaluation of one's physical attractiveness (Banister, 2000; Rubenstein \& Foster, 2013).

In adulthood children leave their family home; this state of affairs results in redefinition of the marital relationship, and leads to changes in family functioning (Henry \& Miller, 2004). The image of menopause may also depend on the fact that the children grow up and move out. Women who perceive the fact in positive terms will be glad to get more free time for themselves and their spouses, while women who perceive it in negative terms will concentrate on the emptiness in their life (Lindh-Åstrand, Hoffmann, Hammar, \& Kjellgren, 2007).

Longer marriage experience is associated with a decrease in positive communicative behaviour between the married couple; thereby it can lead to more frequent use of hard persuasion practices, such as coercion (Mandal, 2014). As a consequence, the use of hard persuasion practices leads to lower satisfaction in marriage (Cereniewicz, 2008).
Lack of satisfaction from one's marriage is related to more intensively experiencing menopause symptoms and negatively influences women's quality of life during perimenopause (Karacam \& Erkan Seker, 2007; Robinson Kurpius, Foley Nicpon, \& Maresh, 2001). Robinson Kurpius et al. (2001) proved that married couples reporting lower satisfaction were more hostile towards and angry at each other, which had an impact on an increased number of menopause symptoms. Wives' well-being is negatively affected by insufficient interest paid by their husbands, insufficient time spent together, ineffective communication and experiencing conflicts related to bringing up their children (Franks \& Stephens, 1992).

The research on the topic confirmed that women who get involved in physical exercise experience less severe menopause symptoms. Physical activity has a significant impact on decreasing the number of menopause symptoms experienced by women; its greatest effect can be observed in depressive women (Albrecht et al., 2009). The research by Elavsky and McAuley (2009) indicates that both walking and practising yoga for four months decrease the number of menopause symptoms reported by women. Another study showed that practising aerobics for six months improves women's sleeping quality and reduces frequency of hot flushes (Eija et al., 2012). Elavsky and McAuley (2005) found that physically active women not only experience fewer menopause symptoms and describe them as less severe, but also more highly evaluate their own physical fitness and report higher life-satisfaction.

The choice of sport discipline may depend on various motives: a desire to be perceived as attractive and low evaluation of one's attractiveness are conducive to practising alone; such persons may get involved in physical exercise in public only in groups consisting of persons of similar appearance and a similar level of physical fitness (Mandal, 2004). Moreover, the choice of a sport discipline may depend on gender stereotypes, according to which women's participation in some sport disciplines, such as aerobics, gymnastics and Nordic walking, finds greater social acceptance than e.g. weight-lifting, considered rather manly (Mandal, 2004; Koivula, 2001).

\section{AIM OF THE STUDY}

The aim of the research is to identify relations between the perception of menopause, life satisfaction and tactics used to exert influence on one's spouse in perimenopausal women involved in physical exercise or avoiding any physical activity. We wanted to find out whether involvement in physical exercise has an impact on functioning of women in the climacteric period and, if so, how it works. A hypothesis was formulated that women involved in
Physical activity in perimenopausal women 
Eugenia Mandal, Magdalena Sitko-Dominik physical exercise are more likely to positively evaluate menopause than women avoiding physical activity. It was expected that physically active women would achieve greater life satisfaction; that there would be a relation between a positive evaluation of menopause and more frequent use of positive and soft tactics of exerting influence on one's spouse; and that there would be differences in the use of particular tactics of exerting influence on one's spouse depending on whether women were physically active or not.

\section{PARTICIPANTS AND PROCEDURE}

\section{RESPONDENTS}

The research group consisted of 90 women: 45 involved in physical exercise and 45 avoiding any physical activity. The criteria for the selection of the research sample were the following: being in wedlock and being at least 45 and not older than 55 . The research was conducted from March to December 2015 among inhabitants of Opolskie, Śląskie, Mazowieckie and Pomorskie provinces. The respondents were selected by means of "snowball" sampling.

Women were classified as physically active if they were involved in physical exercise at least once a week. The majority of the women participating in the research $(30 \%)$ were physically active in two or more sport disciplines. The most popular forms of physical activity were cycling (22\%), Nordic walking (20\%), fitness training (12\%), and jogging (10\%), while the least frequent discipline was swimming (6\%). The research participants preferred to exercise in a group of friends (34\%) or alone $(30 \%)$. Getting involved in physical activity with a husband was reported by $18 \%$ of women, while getting involved in physical activity with different people was reported by $14 \%$. Least frequently the women indicated getting involved in physical activity with children $-4 \%$.

The group of women who are not involved in any physical activity consisted of women who stated that they did not practise any sport for at least one year.

The average age of the respondents was $M=50.64$, $S D=3.87$, the average marital experience was $M=25.71, S D=8.34$. The majority of women lived in rural areas $(40 \%)$ or in towns with over 100,000 inhabitants (33\%), while $27 \%$ lived in towns with less than 100,000 inhabitants. Among the women, 36\% had higher education, 39\% had secondary education, and $25 \%$ had occupational training. In addition, the majority of respondents were economically active $(80 \%), 4 \%$ were on a disability pension, and $16 \%$ were on a retirement pension. Physically active women did not differ from women avoiding physical activity in terms sociodemographic variables (see Table 1).

\section{PROCEDURE}

The research was conducted among people who agreed to participate in it and met the criteria for the selection of the research group. The respondents were given a set of three questionnaires which were arranged in random order. The research had an individual character. None of the tests was conducted through the Internet. None of the respondents received any remuneration for participating in the research.

The results of the research were analysed with the data analysis tool Statistica 12.5.

Table 1

Physical activity as a variable differentiating women with respect to sociodemographic variable

\begin{tabular}{|c|c|c|c|}
\hline & & $\begin{array}{l}\text { Women avoiding } \\
\text { physical activity }\end{array}$ & $\begin{array}{c}\text { Physically } \\
\text { active women }\end{array}$ \\
\hline \multicolumn{2}{|l|}{ Average age } & 51.09 & 50.20 \\
\hline \multicolumn{2}{|c|}{ Average marital experience } & 26.80 & 24.60 \\
\hline \multirow{3}{*}{$\begin{array}{l}\text { Place of } \\
\text { residence }\end{array}$} & Rural area & $42.00 \%$ & $38.00 \%$ \\
\hline & Towns with over 100,000 inhabitants & $33.00 \%$ & $20.00 \%$ \\
\hline & Towns with less than 100,000 inhabitants & $25.00 \%$ & $42.00 \%$ \\
\hline \multirow{3}{*}{ Education } & Occupational training & $27.00 \%$ & $24.00 \%$ \\
\hline & Secondary education & $40.00 \%$ & $38.00 \%$ \\
\hline & Higher education & $33.00 \%$ & $38.00 \%$ \\
\hline \multirow{3}{*}{$\begin{array}{l}\text { Professional } \\
\text { activity }\end{array}$} & Economically active & $78.00 \%$ & $82.00 \%$ \\
\hline & Disability pension & $7.00 \%$ & $2.00 \%$ \\
\hline & Retirement pension & $15.00 \%$ & $16.00 \%$ \\
\hline
\end{tabular}


In the study the following research tools were used:

- The Menopause Evaluation Scale (Bielawska-Batorowicz, 2005) is a tool used to determine attitudes towards menopause. It enables researchers to measure attitudes - positive, neutral and negative. The scale consists of 35 statements which have to be evaluated by the respondents on a five-level Likert scale. The result of a given scale is the sum of points received for particular items ascribed to this scale. In the conducted research, internal consistency for the Positive Scale equalled $\alpha=.91$, for the Negative Scale $\alpha=.90$, and for the whole tool $\alpha=.85$.

- The Satisfaction With Life Scale (SWLS, Diener, Emmons, Larsen, \& Griffin, 1985; Polish version - Juczyński, 2009) enables researchers to evaluate satisfaction with life. The scale consists of 5 statements which have to be evaluated by the respondents on a seven-level scale. The general result is the sum of points obtained for particular items. The internal consistency of the tool was $\alpha=.87$.

- The Questionnaire of Influence Tactics in Close Relationships of Women and Men (Mandal, 2014) measures tactics of exerting influence in close relationships. The tool consists of 35 statements referring to three groups of tactics of social influence - hard tactics: Threats and violence, Complaining and quarrelling, Quiet days and sulks; intermediate tactics: Persistence and obstinacy, Argumentation and requests, The partner's authority, One's own authority; soft tactics: Exchange and favours, Romanticism and surprises, Clumsiness and cuddling. The respondents evaluate each statement on a seven-level scale. The average evaluation of an item on a particular scale is the result of the scale. In the conducted research the internal consistency of the tool was $\alpha=.95$.
A comparison of women involved in physical exercise and those avoiding physical activity by means of the Student's $t$-test confirmed the hypothesis about a stronger tendency to positively evaluate menopause among physically active women in comparison to women avoiding physical activity (see Table 2).

The research showed that physically active women on average express greater life satisfaction than those who avoid physical activity, but the difference was not statistically significant $(p=.064)$ (see Table 2 ).

An analysis of Pearson's correlation between tactics of exerting influence on one's spouse and menopause evaluation showed that there is a relation between one of the intermediate tactics and soft tactics, and the positive evaluation of menopause. Thus the women having a positive image of menopause were likely to more frequently use the tactics of Argumentation and requests, Exchange and favours, Romanticism and surprises and Clumsiness and cuddling. A relation between tactics of exerting influence on one's spouse and negative evaluation of menopause was not observed (see Table 3).

On the basis of the research conducted using the parametric Student's $t$-test, it was confirmed that involvement in physical exercise differentiates women in respect of the frequency of the use of tactics of exerting influence on one's spouse. Thus women involved in physical exercise were more likely to apply the following tactics: Argumentation and requests, Romanticism and surprises and Clumsiness and cuddling. All the results were statistically significant. The other tactics of social influence did not differentiate between the research groups (see Table 4).

\section{DISCUSSION}

The research has confirmed a relationship between physical activity and a positive attitude to meno-
Physical activity in perimenopausal women

Table 2

Physical activity as a variable differentiating women with respect to selected variables. Results of Student's t-test for two independent samples

\begin{tabular}{|c|c|c|c|c|c|c|}
\hline & \multicolumn{2}{|c|}{$\begin{array}{l}\text { Women avoiding } \\
\text { physical activity }\end{array}$} & \multicolumn{2}{|c|}{$\begin{array}{l}\text { Physically } \\
\text { active women }\end{array}$} & \multirow[t]{2}{*}{$t(88)$} & \multirow[t]{2}{*}{$p$} \\
\hline & $M$ & $S D$ & $M$ & $S D$ & & \\
\hline Life satisfaction & 21.62 & 5.88 & 23.89 & 5.56 & -1.88 & .064 \\
\hline Positive Scale of Menopause Evaluation & 39.96 & 9.47 & 48.51 & 10.04 & -4.16 & $<.001$ \\
\hline Negative Scale of Menopause Evaluation & 42.40 & 8.91 & 33.18 & 10.55 & 4.48 & $<.001$ \\
\hline $\begin{array}{l}\text { Difference between Positive and Negative } \\
\text { Scale of Menopause Evaluation }\end{array}$ & -2.44 & 10.98 & 15.33 & 14.91 & -6.44 & $<.001$ \\
\hline
\end{tabular}

Note. The nonparametric Mann-Whitney $U$-test conducted for the variables characterized by lack of normal distribution gave identical results. 
Table 3

Scale of menopause evaluation and tactics of influence on one's spouse. Pearson's correlation coefficients

\begin{tabular}{lcc}
\hline & $\begin{array}{c}\text { Positive scale } \\
\text { of menopause evaluation }\end{array}$ & $\begin{array}{c}\text { Negative scale of } \\
\text { menopause evaluation }\end{array}$ \\
\hline Threats and violence & .16 & .20 \\
Complaining and quarrelling & .03 & .16 \\
Quiet days and sulks & .20 & .04 \\
Persistence and obstinacy & .16 & -.03 \\
Argumentation and requests & $.25^{*}$ & -.14 \\
Partner's authority & .11 & -.02 \\
One's own authority & .18 & .00 \\
Exchange and favours & $.30^{* *}$ & .07 \\
Romanticism and surprises & $.25^{*}$ & -.04 \\
Clumsiness and cuddling & $.27^{*}$ & -.06 \\
\hline
\end{tabular}

Note. ${ }^{* *} p<.01,{ }^{*} p<.05$

An analysis of Spearman's rank correlation conducted for the variables characterized by lack of normal distribution gave identical results.

Table 4

Involvement in physical exercise and tactics of influence on one's spouse. Results of Student's t-test for two independent samples

\begin{tabular}{|c|c|c|c|c|c|c|}
\hline & \multicolumn{2}{|c|}{$\begin{array}{l}\text { Women avoiding } \\
\text { physical activity }\end{array}$} & \multicolumn{2}{|c|}{$\begin{array}{c}\text { Physically } \\
\text { active women }\end{array}$} & \multirow[t]{2}{*}{$t(88)$} & \multirow[t]{2}{*}{$p$} \\
\hline & $M$ & $S D$ & $M$ & $S D$ & & \\
\hline Threats and violence & 1.63 & 1.10 & 1.87 & 1.09 & -1.07 & .286 \\
\hline Complaining and quarrelling & 2.96 & 2.02 & 3.11 & 1.71 & -0.38 & .708 \\
\hline Quiet days and sulks & 2.40 & 1.47 & 2.96 & 1.65 & -1.70 & .093 \\
\hline Persistence and obstinacy & 3.56 & 1.70 & 4.05 & 1.62 & -1.39 & .167 \\
\hline Argumentation and requests & 4.37 & 1.48 & 5.15 & 1.37 & -2.59 & .011 \\
\hline Partner's authority & 3.80 & 1.71 & 3.90 & 1.73 & -0.28 & .783 \\
\hline One's own authority & 4.10 & 1.45 & 4.59 & 1.40 & -1.62 & .108 \\
\hline Exchange and favours & 2.48 & 1.36 & 3.01 & 1.47 & -1.75 & .083 \\
\hline Romanticism and surprises & 2.74 & 1.43 & 3.67 & 1.62 & -2.88 & .005 \\
\hline Clumsiness and cuddling & 2.84 & 1.54 & 3.57 & 1.69 & -2.13 & .036 \\
\hline
\end{tabular}

Note. The nonparametric Mann-Whitney $U$-test conducted for the variables characterized by lack of normal distribution gave identical results.

pause, satisfaction from life and tactics of exerting social influence in marriages of perimenopausal women.

Women involved in physical activity showed a positive attitude towards menopause more frequently than women who avoided physical activity. A positive impact of the women's physical activity on their attitude towards menopause may result from a positive impact of their physical activity on their health and may be an effect of receiving pos- itive reinforcements; physical activity is positively evaluated as an important element of self-care and healthy life-style. It may also be assumed that having a positive attitude towards menopause may be related to fewer menopause symptoms being experienced by physically active women (Bloch, 2002). A positive attitude towards menopause being more frequent among physical active women corresponds to the research which confirms that experiencing menopause less frequently has an impact on a positive attitude 
towards the phenomenon (Papini, Intrieri, \& Goodwin, 2002).

The analysis of the relation between the evaluation of subjective satisfaction with life and physical activity confirmed that physically active women showed slightly higher satisfaction with life in comparison to women who avoid any physical activity. Many studies confirm the relation between physical activity and greater satisfaction with life (Elavsky \& $\mathrm{McAu}-$ ley, 2005, 2009); however, it is worth noting that there are also studies which do not confirm this tendency (Ornes, Ransdell, Robertson, \& Moyer-Mileur, 2005).

The analysis of exerting influence on their spouses and their attitude towards menopause showed that the tactics considered preferable by perimenopausal women were significantly related to having a positive image of menopause. Women evaluating menopause on a positive scale most frequently used the following tactics: Exchange and favours, Clumsiness and cuddling, Romanticism and surprises, and Argumentation and requests. These are positive tactics, pleasant for the partner to be influenced. The use of the tactics may tone down tensions and conflicts and increase the sense of satisfaction with marriage (Mandal, 2014). It can be assumed that a positive attitude towards menopause is also related to having greater satisfaction with marriage. Correlations between satisfaction with a close relationship and tactics of exerting influence are confirmed by the research which showed that spouses reporting greater satisfaction with their relationship more frequently use soft tactics of exerting social influence (Cereniewicz, 2008).

The analysis of the relationship between physical activity and exerting social influence on one's spouse showed that physically active women have a higher tendency to use the Argumentation and requests tactic, and a slightly lower tendency to use the tactics of Romanticism and surprises, and Clumsiness and cuddling, in comparison to women showing a negative attitude towards menopause. It may result from the fact that thanks to physical activity the women have not only a more positive image of their body (Hausenblas \& Fallon, 2006), but they may also evaluate their physical attractiveness more highly.

Moreover, physical exercises may increase physical fitness and sexual condition, and at the same time positively influence relations between the married couple. Using direct and positive tactics in order to exert influence on one's spouse may also be related to the fact that getting involved in physical activity is an effective way to deal with stress which occurs in this period of life. As a result of physical activity, stress in marriage is not relieved by means of negative, destructive, hard tactics of exerting influence, related, e.g. to silent treatment or physical violence (Cassidy, 2000). Physical activity turns out to be a positive factor in achieving well-being and satisfaction with life in marriage.

\section{CONCLUSIONS}

Physical activity is related to having often a positive attitude towards menopause and leads to slightly higher life satisfaction. The research has shown that women who are physically active have a positive attitude towards menopause and prefer to use more frequently direct and soft tactics of exerting influence on their spouses. The result may testify to the women's more effective management of stress related to menopause and not submitting to the negative image of menopause existing in Western culture. As physical activity has a positive impact on perimenopausal women, they should be encouraged to get involved in physical exercise.

\section{LIMITATIONS OF THE STUDY}

The research results may be related not only to the women's physical activity but also to their economic status, professional work, family obligations and their free time. Women with high economic status, who have many professional and family obligations, and who have more free time, may be more physically active, be more satisfied with their life and marriage, and more positively perceive the period of menopause irrespective of physical activity. In addition, the relatively small sample size may have an influence on these findings.

Differences in preferences concerning hard or soft tactics of exerting influence on one's spouse may be related to the women's satisfaction with their marriage, and to a lesser extent to their attitude towards menopause and to getting involved in physical activity. We suggest further research on the relations between physical activity and close relationships.

\section{References}

Adler, S. R., Fosket, J. R., Kagawa-Singer, M., McGraw, A. A., Wong-Kim, E., Gold, E., \& Sternfeld, B. (2000). Conceptualizing menopause and midlife: Chinese American and Chinese Women in the US. Maturitas, 35, 11-23.

Albrecht, A., Farrell, N. C., Marcus, B. H., McAndrew, L. M., Napolitano, M. A., \& Whiteley, J. A. (2009). When, why and for whom there is a relationship between physical activity and menopause symptoms. Maturitas, 64, 119-125.

Avis, N. E., \& McKinlay, S. M. (1991). A longitudinal analysis of women's attitudes toward the menopause: results from the Massachusetts Women's Health Study. Maturitas, 13, 65-79.

Banister, E. M. (2000). Women's midlife confusion: "Why am I feeling this way?". Issues in Mental Health Nursing, 21, 745-764.
Physical activity in perimenopausal women 
Bielawska-Batorowicz, E. (2005). Konstrukcja i zastosowanie skali Ocena Menopauzy [The construction and use of the scale Menopause Evaluation]. Acta Universitatis Lodziensis Folia Psychologica, 9, 31-39.

Bielawska-Batorowicz, E., Cieślik, I., \& Cwalina, E. (2003). Rola płci i wieku w tworzeniu obrazu kobiety $w$ okresie menopauzy [The role of gender and age in creating an image of perimenopausal woman]. Przeglad Menopauzalny, 6, 68-73.

Eugenia Mandal,

Magdalena

Sitko-Dominik

Bloch, A. (2002). Self-awareness during the menopause. Maturitas, 41, 61-68.

Cassidy, T. (2000). Stress, healthiness and health behaviours: An exploration of the role of life events, daily hassles, cognitive appraisal and the coping process. Counselling Psychology Quarterly, 13, 293-311.

Cereniewicz, M. (2008). Postawić na swoim czy nie? Związki między taktykami wywierania wpływu małżonków a satysfakcją małżeńską [To have one's will or not? Relations between tactics of exerting influence and satisfaction with marriage]. Psychologia Jakości Życia, 1-2, 47-69.

Diener, E., Emmons, R. A., Larsen, R. J., \& Griffin, S. (1985). The Satisfaction With Life Scale. Journal of Personality Assessment, 49, 71-75.

Eija, T., Heinonen, R., Luoto, R., Mansikkamaki, K., Mikkola, T., Nygard, C. H., \& Raitanen, J. (2012). Sleep quality and aerobic training among menopausal women - a randomized controlled trial. Maturitas, 72, 339-345.

Elavsky, S., \& McAuley, E. (2009). Personality, menopausal symptoms, and physical activity outcomes in middle-aged women. Personality \& Individual Differences, 46, 123-128.

Elavsky, S., \& McAuley, E. (2005). Physical activity, symptoms, esteem, and life satisfaction during menopause. Maturitas, 52, 374-385.

Franks, M. M., \& Stephens, P. A. (1992). Multiple roles of middle-generation caregivers: Contextual effects and psychological mechanisms. Journal of Gerontology: Social Sciences, 47, 123-129.

Fredrickson, B. L., \& Roberts, T. (1997). Objectification theory: Toward understanding women's lived experiences and mental health risks. Psychology of Women Quarterly, 21, 173-206.

Gannon, L., \& Stevens, J. (1998). Portraits of Menopuse in the Mass Media. Women \& Health, 27, 1-15.

Hausenblas, H. A., \& Fallon, E. A. (2006). Exercise and body image: A meta-analysis. Psychology and Health, 21, 33-47.

Henry, R. G., \& Miller, R. B. (2004). Marital problems occuring in midlife: implications for couples therapists. The American of Journal of Family Therapy, 32, 405-417.

Hvas, L. (2001). Positive aspects of menopause: a qualitative study. Maturitas, 39, 11-17.
Juczyński, Z. (2009). Narzędzia pomiaru w promocji i psychologii zdrowia [Measure tools in health promotion and health psychology]. Warszawa: Pracownia Testów Psychologicznych.

Karacam, Z., \& Erkan Seker, S. (2007). Factors associated with menopausal symptoms and their relationship with the quality of life among Turkish women. Maturitas, 58, 75-82.

Koivula, N. (2001). Perceived characteristics of sports categorized as gender-neutral, feminineand masculine. Journal of Sport Behavior, 24, 377-393.

Lindh-Åstrand, L., Hoffmann, M., Hammar, M., \& Kjellgren, K. I. (2007). Women's conception of the menopausal transition - a qualitative study. Journal of Clinical Nursing, 16, 509-517.

Mandal, E. (2014). Kwestionariusz wywierania wpływu społecznego w bliskich związkach kobiet i mężczyzn [The Questionnaire of Influence Tactics in Close Relationships Women and Men]. Przegląd Psychologiczny, 57, 193-211.

Mandal, E. (2004). Podmiotowe i interpersonalne konsekwencje stereotypów związanych z ptcia [The individual and interpersonal consequences of the gender stereotype]. Katowice: Wydawnictwo Uniwersytetu Śląskiego.

Ornes, L. L., Ransdell, L. B., Robertson, L., \& Moyer-Mileur, L. (2005). A 6-month pilot study of effects of a physical activity intervention on life satisfaction with a sample of three generations of women. Perceptual \& Motor Skills, 100, 579-591.

Papini, D. R., Intrieri, R. C., \& Goodwin, P. E. (2002). Attitude toward menopause among married middle-aged adults. Women \& Health, 36, 55-68.

Randall, T. (1993). Women need more and better information on menopause from their physicians, says survey. Journal of the American Medical Association, 270, 1664.

Robinson Kurpius, S. E., Foley Nicpon, M. F., \& Maresh, S. E. (2001). Mood, marriage and menopause. Journal of Counseling Psychology, 48, 77-84.

Rubenstein, H. R., \& Foster, J. L. (2013). 'I don't know whether it is to do with age or to do with hormones and whether it is to do with a stage in your life': making sense of menopause and the body. Journal of Health Psychology, 18, 292-307. 